\title{
Learning Obstacle the Addition and Subtraction of Fraction in Grade 5 Elementary Schools
}

\section{Irfan Fauzi}

Elementary Education Study Program, School of Postgraduate, Universitas Pendidikan Indonesia, Bandung, Indonesia

Email:if96@upi.edu

\section{Didi Suryadi}

Department of Mathematics Education, Faculty of Mathematics and Natural Science, Universitas Pendidikan Indonesia, Bandung, Indonesia Email:ddsuryadi1@gmail.com

\begin{abstract}
The Fraction is a material that is very important for students to learn in elementary school, but various difficulties are shown by students in understanding the material, so this study will analyze the learning obstacle that appears to students in the addition and subtraction material in grade 5 elementary school. The approach in this research uses qualitative and case study methods. The subjects in this study were $5^{\text {th }}$-grade students of Geger Kalong Girang 1-2 elementary schools, Bandung City, West Java, Indonesia with a total of 29 students. Data was collected by tests, interviews, and documentation, while for data analysis techniques using data reduction, data presentation, and conclusions. The results of this study indicated that students experience learning obstacles, including 1) ontogenic obstacle, which is the inability of students to understand the purpose of the problems presented; 2) epistemological obstacle, namely the inability of students to understand the concept of fractions is part of the whole and the inability of students to do the addition and subtraction of fractions, and; 3) didactical obstacle caused by the presentation of material and the teacher's way of teaching which is only informal. This research is expected to facilitate students to understand fractions and be a development material in making teaching materials and didactic design of
\end{abstract}




\section{Mudarrisa: Jurnal Kajian Pendidikan Islam, Vol. 12, No. 1, 2020}

the addition and subtraction fractions based on learning obstacles that appear in this study.

Keywords: addition and subtraction of fractions, learning obstacle, elementary school

\section{INTRODUCTION}

Mathematics is one of the most important lessons for students to understand (Gravemeijer et al., 2017), because mathematics is used in everyday life and can support the progress of science and technology (Surya et al., 2017) then, in the context of learning, mathematics is seen as a subject that can encourage various abilities such as logical thinking, analytical, systematic, critical, and creative, as well as the ability to work together (Lince, 2016). This is the reason mathematics is taught from elementary to higher education (Susana, 2017). But, mathematics is seen as a subject that is very difficult to understand (Fathurrohman et al., 2009; Zengin, 2017), this is also evident from various studies that explain that student learning outcomes in mathematics learning are very low (Sappaile, 2007), supported by the low PISA results in 2019 which showed that Indonesia was ranked 73 out of 79 countries in mathematics (Prastyo \& Salman, 2020), one of the reasons is because mathematics is a deductive and abstract science that uses symbolic language, while the development of children's thinking is still at a concrete operational stage (Widodo \& Kartikasari, 2017), this is the teacher's job to create meaningful learning and by the real conditions experienced by students. 
One of the subject matter in mathematics is fractions, fractional material in Indonesia has been taught from the beginning of the lower classes (Oktaviani \& Mampouw, 2018), and it continues to be studied until high class. One of the fraction topics that are very important for students to understand is fraction addition and subtraction, and that topic is in grade 5. The details of the material are explained in the basic competencies based on Permendikbud number 37 the year 2018.

Table 1. Fractional Material in Grade 5 Elementary Schools

\begin{tabular}{cll}
\hline Learning & \multicolumn{4}{c}{ Material } \\
\hline 1 & $\begin{array}{l}\text { Addition and subtraction of two fractions with different } \\
\text { denominators }\end{array}$ \\
\hline 2 & Multiplication and division of fractions and decimals \\
\hline
\end{tabular}

The fraction in Table 1 is a very important material for students to understand because students' understanding of the fraction addition and subtraction material will form knowledge and become the basis for them to deal with more complex material at the next level, this is also explained by Siegler et al (2012) that there is a strong positive relationship between students' understanding of fractions and their overall success in learning mathematics. However, fractional material is also seen by students as material that is very difficult to understand, it can be seen from various studies that show it (Deringol, 2018; Gabriel et al., 2013; Nguyen et al., 2017; Ramlah et al., 2017).

Difficulties experienced by students in understanding fraction material must be identified in the learning process, the identification process must involve several factors including students, teaching materials and, teachers because this is a basic element in learning (Suryadi, 2010). 
Analysis of learning obstacle becomes the thing that needs to be done in analyzing various student difficulties, according to Brosseaou (2002) learning obstacle is divided into 3 of them are 1) ontogenic obstacle is a learning barrier that occurs because of the limitations of the students themselves in personal development or related to the mental readiness of student learning; 2) epistemological obstacle is an obstacle that occurs because of the limited knowledge possessed by students in certain contexts, and; 3) didactical obstacles that arise from the methods or approaches used by teachers and the presentation of material in textbooks.

This study will analyze students' obstacle learning on fraction addition and subtraction material in grade 5 elementary school, this study can facilitate students to understand more about fractions, besides being a material for teachers in making teaching materials and instructional design on fraction addition and subtraction material in grade 5 elementary school.

\section{METHODS}

This research uses a qualitative approach. According to Lestari \& Yudhanegara (2015) that qualitative research is methods for exploring and understanding the meaning by several individuals or groups of people ascribed to social or humanitarian problems, then the qualitative approach is very suitable to be used in uncovering various central phenomena that emerge in this study. The method used is a case study, according to Gall et al (1999) that case studies are carried out to explain certain phenomena, 
such as individuals, programs, processes, and so on. So, the case study is considered as the right method to reveal in detail students' obstacle learning on fraction addition material in grade 5 elementary school.

This research was conducted at Geger Kalong Girang 1-2 elementary school. Participants in this study were grade 5 elementary school students with a total of 29 students. Data collection techniques in this study using 1) tests, according to Arikunto (2013) tests are a series of questions or exercises or other tools used to measure skills, knowledge, intelligence, abilities, or talents possessed by individuals or groups. Written tests are given to students to see the obstacle learning that appears related to the addition and subtraction of fractions in grade 5 elementary school; 2) interview, according to Margono (2007) that an interview is an information-gathering tool by asking several questions verbally to be answered verbally as well. In this study, interviews were given to students to uncover the mindset or reasons students gave answers as stated in the questions given, interviews were also given to the teacher in seeing the concept of the teacher's shadow and teaching strategies on the material addition and subtraction fractions in grade 5 elementary school, and; 3) documentation, according to Arikunto (2013) that documentation is looking for data about things or variables in the form of notes, transcripts, books, books, newspapers, magazines, inscriptions, minutes of meetings, loops, agendas and so on. The documentation used in this study was to analyze grade 5 textbooks used in the learning process about addition and subtraction of fractions. 
Data collection is carried out as follows (1) Students are asked to answer individual obstacle learning test questions; (2) student workmanship in the form of scribbles in the form of supporting data written test results, and (3) researchers take some answers students who experience obstacles learn to be interviewed. The data that has been obtained is used as a basis in identifying and analyzing student obstacle learning that appears in the addition and subtraction material infractions in grade 5 elementary schools. The data analysis was carried out as follows 1) data reduction, the researcher recorded all student responses when answering the question of addition and subtraction of fractions; 2) data presentation, researchers classify various difficulties students and identify them, and; 3) conclusions, the researcher analyzes in detail the difficulty of students in understanding the addition and subtraction of fractions using the obstacle learning theory.

\section{DISCUSSION}

Obstacle learning test given to students in grade 5 at Geger Kalong Girang 1-2 elementary school, Bandung city, which amounted to 29 students, the test is given is then identified to see the students 'obstacles, from various responses that appear on students' answers, the researcher noted that several obstacles occurred, including the 1) the inability of students to understand the purpose of the questions presented; 2) the inability of students to understand the concept of fractions that are part of the whole, and; 3) the inability of students to add and subtract fractions. 


\section{Ontogenic Obstacle}

The Ontogenic obstacle found in students is the inability of students to understand the purpose of the picture presented in the problem and shown in Figure 1.

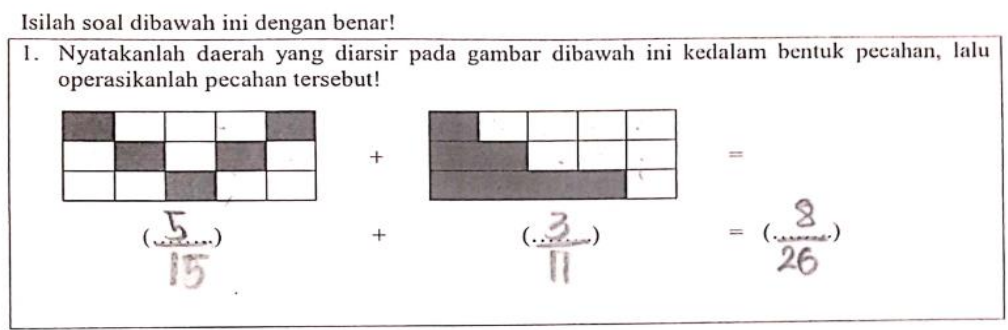

Figure 1. Ontogenic Obstacle 1

In Figure 1, two shaded images are presented, the first picture has five shaded parts that have the same size, and the second picture is presented with three shaded parts but of different sizes. In simple terms, students already understand the concept of fractions is part of the whole in a simple way, seen when students write the fraction answers correctly in the first picture, but in the second picture, students feel confused with the questions presented, based on the results of interviews with students, that they are focused on the shaded part of the picture, even though the picture has a different size from the others, students should be able to solve it by making a line downward, so that the parts become the same, and it can be expressed in the form of fractions as part of a whole that has the same size.

The same thing is done by students in solving other problems, the problem is very related to the previous problem because it has the same 
concept, while the indicators developed are introducing the concept of arithmetic operations of addition and subtraction of fractions.

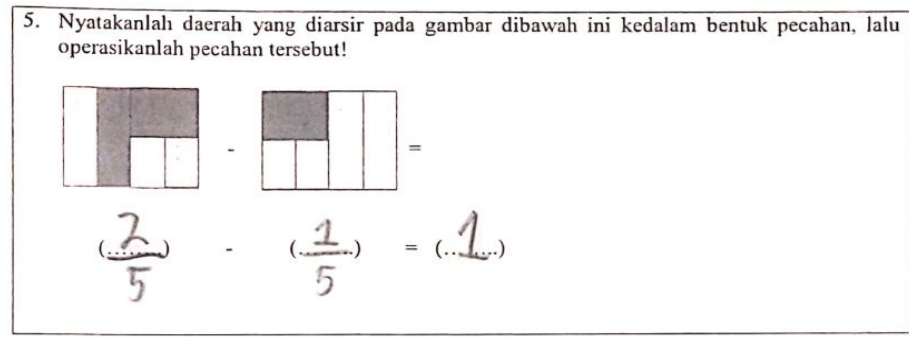

Figure 2. Students calculate the shaded area without regard to size

Usually, students get a picture problem infractions of the same size, so they can immediately determine the amount of the fraction, but in the picture above they present problems that they did not normally find before, so this causes difficulties for students to answer the question. Students focus on the shaded image regardless of the size of the image. It can be said that the obstacle above is ontogenic, namely, the inability of students to understand the shape of the image presented so that it is wrong to determine the fractional value of an image, according to Malikha $\&$ Amir (2018) that it is related to the meaning of fractions which means that part of the whole is interpreted differently by students, ie students do not pay attention to parts of the whole amount of fair or not. According to Suryadi (2018) explain that students who are always given material too easily will be hampered by the development of their thinking.

\section{Epistemological Obstacle}

The first epistemological obstacle related to the inability of students to understand the concept of fractions is part of the whole (part to whole). 


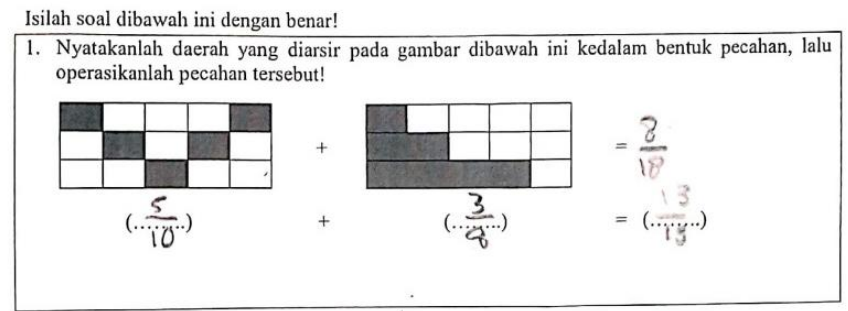

Figure 3. Epistemological Obstacle 1

Usually, students get a picture problem infractions of the same size, so they can immediately determine the amount of the fraction, but in the picture above, presented a problem that they usually did not find before, so this causes difficulties for students to answer the question. Students focus on the shaded image regardless of the size of the image. Then based on the results of the interview that the way students do in expressing a fraction of the picture is to count one by one shaded part and compare it with the unshaded, this shows that students do not understand fractions are part of the whole, the difficulty is also found in several studies on fractions such as Rohmah (2019), \& Wijaya (2017).

The second epistemological obstacle is related to the way students operate fractions. There are many responses to the difficulties of students in answering questions of addition and subtraction of fractions, including them:

Immediately add up or subtract the numerator by the numerator and the denominator by the denominator Based on the results of the interview that in completing the addition and subtraction of fractions, students directly add or subtract the denominator parts with the denominator and numerator with the numerator. 
Mudarrisa: Jurnal Kajian Pendidikan Islam, Vol. 12, No. 1, 2020

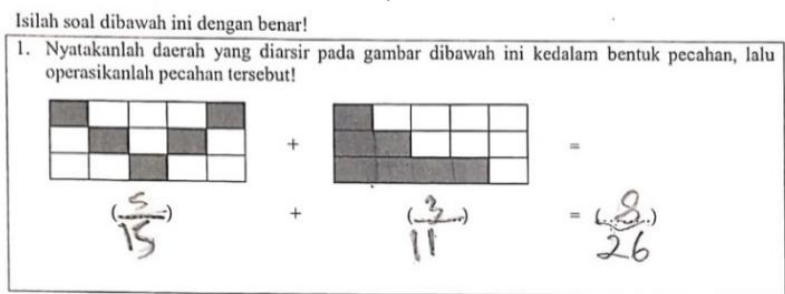

Figure 4. The Difficulty of students in operating fractions 1

Students do not understand that when adding or subtracting fractions that have different denominators, they must first be equated and then operate them by only adding the numerator part and the denominator part are the same number.

The way students do:

$\frac{5}{15}+\frac{3}{11}=\frac{5+3}{15+11}=\frac{8}{26}$

Equate the denominator of a fraction then the result of the number is divided by the denominator and add it to the numerator

Based on the results of the interview that in solving the problem of adding and subtracting fractions, the way students do is to equate the denominator of the fraction and then the results of the numbers are divided by the denominator and add to the numerator, after which the new student operates it.

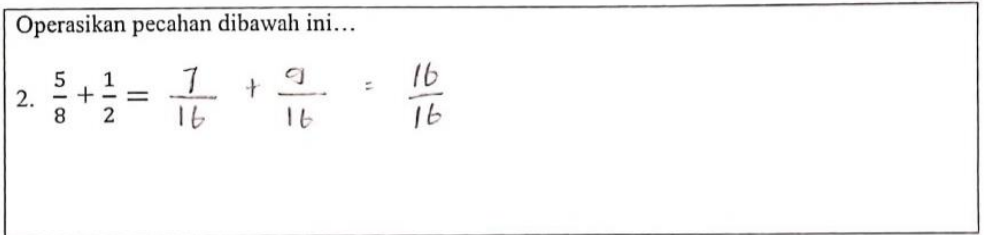

Figure 5. The Difficulty of students in operating fractions 2 
The way students do the way below:

$\frac{5}{8}+\frac{1}{2}=\frac{(\ldots)}{(8 \times 2)}+\frac{(\ldots)}{(2 \times 8)}=\frac{(16 \div 8+5)}{16}+\frac{(16 \div 2+1)}{16}=\frac{7}{16}+\frac{9}{16}=\frac{16}{16}$

Using procedures that are not systematic

Based on the results of the interview that in solving the problem of adding and subtracting fractions, the way students do is to equate the denominator of the fraction and then the results of the numbers are divided by the denominator and add to the numerator, after which the new student operates it.

Operasikan pecahan dibawah ini...
2. $\frac{5}{8}+\frac{1}{2}=\frac{6}{10}+\frac{5}{8}=\frac{11}{18} \times \frac{8}{5}=\frac{170}{90}$

Figure 6. The Difficulty of students in operating fractions 3

Based on the results of the interview that students used the principle of completing the addition calculation operations that they did not fully understand, they also said that they forgot how to add fractions with different denominators.

Difficulties of students in operating fractions are found in various studies (Kania, 2018; Suarjana et al., 2018; Suciati \& Wahyuni, 2018), one of the main reasons for students' difficulties in performing arithmetic operations on the fraction addition and subtraction ie they are only memorizing formulas and algorithms, not understand fractions, and assume that the denominator and numerator infractions are two separate integers (Şiap \& Duru, 2004). 


\section{Mudarrisa: Jurnal Kajian Pendidikan Islam, Vol. 12, No. 1, 2020}

\section{Didactical Obstacle}

The obstacles that arise can be caused by the use of teaching strategies and methods in teaching, in addition to the presentation of material in textbooks, it also becomes the basis for the emergence of obstacles students have. Regarding the didactical obstacle, it was found that students had difficulty in representing the shape of the image into the form of fractions.

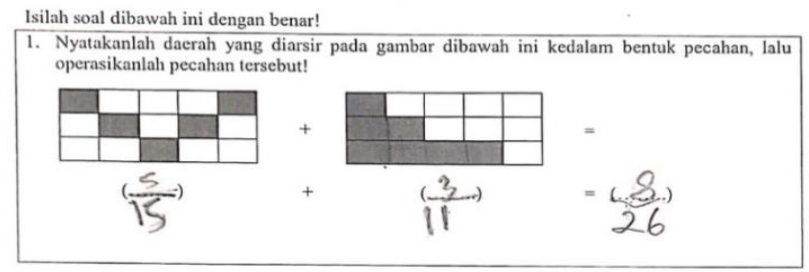

Figure 7. Didactical Obstacle 1

This is because the textbooks do not explain that when presented in the form of drawings that have different sizes, then what must be done is to equate the parts of the different shapes, it is to instill to students that the reasons why in the calculation operations are addition and subtraction of fractions the denominator must be equated first.

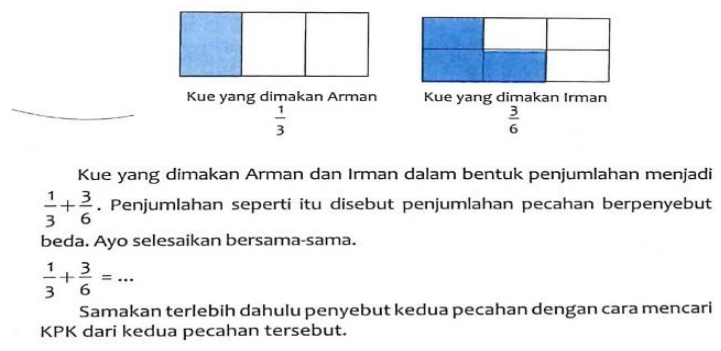

Figure 8. Completing the Addition of Fractions in a Textbook

Although the presentation uses an iconic form, it does not form knowledge to students, this is what causes didactical obstacles. The 
completion of arithmetic operations and subtraction fraction must be taught in full so that the knowledge obtained by students becomes more meaningful.
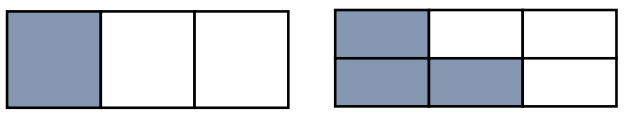

From the picture above, the presentation should not be directly from the image to the symbol, but it must be explained why the addition and subtraction of the fraction are converted into a symbol and the method is likened to the denominator. Then the form of presentation.
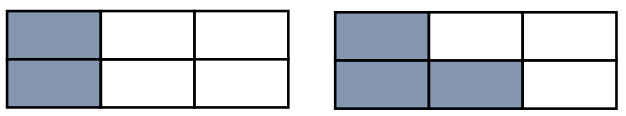

So, it will get the fractions $\frac{2}{6}$ and $\frac{3}{6}$, this is where it starts to be explained that completing the calculation operations of addition and subtraction of the different denominational fractions is carried out by equalizing the denominator first so that the concepts that are built become more meaningful.

The presentation of the textbook above not only raises the didactical obstacle related to fraction representation but also results in the occurrence of another didactical obstacle namely the difficulty of students in completing fraction addition and subtraction operations. Students thought the procedure that when presented with different fragments the way to solve them is equated with the denominator, but they do not fully understand this procedure. 


Operasikan pecahan dibawah ini...
2. $\frac{5}{8}+\frac{1}{2}=\frac{7}{16}+\frac{9}{16}=\frac{16}{16}$

Figure 9. Didactical Obstacle 2

Also, this happens not only because of the presentation of the textbook alone but how teachers teach the operations of calculating addition and subtraction fractions that students do not fully understand about them, the teacher teaches procedurally how to operate the addition and subtraction of fractions that are taught directly symbolically by equating the denominator without students knowing why it should be equated. How to teach teachers who are only informal will have an impact on the learning process, so that the memories formed are only temporary (short time memory), or according to Turmudi (2008), the degree of attachment can also be said to below.

\section{CONCLUSION}

Based on the, it can be concluded that some students experience obstacles in the material addition and subtraction of fractions, while the learning barriers are as follows: 1) ontogenic obstacle namely the inability of students to understand the purpose of the problem presented; 2) epistemological obstacle namely the inability of students in understanding the concept of fractions that are part of the whole and apply the wrong system in completing the addition and subtraction of fractions, and; 3) didactical obstacle which is because the teacher only teaches the addition 
and subtraction material fraction informally, then the presentation of the material in the textbook also pays little attention to student involvement to build their knowledge independently. This research is expected to make a real contribution in the field of education in Indonesia, especially in learning mathematics in elementary schools, the results of this study are expected to facilitate students to understand fractions and be a development material in making teaching materials and didactic design on the fraction addition and subtraction material based on learning obstacles that are appeared in this study.

\section{REFERENCES}

Arikunto, S. (2013). Prosedur Penelitian Suatu Pendekatan Praktik. Jakarta: Rineka Cipta.

Brosseaou, G. (2002). Theory of Didactical Situation in Mathematics. New York, Boston, Dordrecht, London, Moscow: Kluwer Academic Publishers.

Deringol, Y. (2018). Primary School Students' Mathematics Motivation and Anxieties. Cypriot Journal of Educational Sciences, 13(4), 537-548. https://doi.org/10.18844/cjes.v13i4.3462.

Fathurrohman, M., Rahayu, I., \& Nindiasari, H. (2009). Pengembangan Media Pembelajaran Untuk Menghindari Mind In Chaos. Jurnal Ilmu Pendidikan, Vol. 16(2), 106-111.

Gabriel, F., Coché, F., Szücs, D., Carette, V., Rey, B. ., \& Content, A. (2013). A componential view of children's difficulties in learning fractions. Developmental Psychology, 715(4), 1-12.

Gall, M. D., Gall, J. P., \& Borg, W. R. (1999). Applying Educational Research: How to Read, Do, and Use Research (6th ed.). New York: Pearson.

Gravemeijer, K., Stephan, M., Julie, C., Lin, F. L., \& Ohtani, M. (2017). What Mathematics Education May Prepare Students for the 
Society of the Future? International Journal of Science and Mathematics Education, 15, 105-123. https://doi.org/10.1007/s10763-017-9814-6.

Kania, N. (2018). Alat Peraga untuk Memahami Konsep Pecahan. Jurnal THEOREMS (The Original Research of Mathematics), 2(2), 1-12. https://doi.org/http://dx.doi.org/10.31949/th.v2i2.699.

Lestari, K. E., \& Mokhamad Ridwan Yudhanegara. (2015). Penelitian Pendidikan Matematika. Bandung: Refika Aditama.

Lince, R. (2016). Creative Thinking Ability to Increase Student Mathematical of Junior High School by Applying Models Numbered Heads Together. Journal Of Education and Practice, 7(6), $206-212$.

Malikha, Z., \& Amir, M. F. (2018). Analisis Miskonsepsi Siswa Kelas V-B Min Buduran Sidoarjo Pada Materi Pecahan Ditinjau Dari Kemampuan Matematika. Pi: Mathematics Education Journal, 1(2), 75-81. https://doi.org/10.21067/pmej.v1i2.2329.

Margono. (2007). Metodologi Penelitian Pendidikan. Jakarta: Rineka Cipta.

Nguyen, P. L., Duong, H. T., \& Phan, T. C. (2017). Identifying the concept fraction of primary school students: The investigation in Vietnam. Educational Research and Reviews, 12(8), 531-539. https://doi.org/10.5897/err2017.3220.

Oktaviani, N., \& Mampouw, H. L. (2018). Pemberian Scaffolding pada Materi Penjumlahan dan Pengurangan Pecahan bagi Siswa SMP Berkemampuan Matematika Rendah. 1(1), 86-90.

Permendikbud Nomor 37 Tahun 2018 tentang Perubahan atas Permendikbud Nomor 24 Tahun 2016 tentang Kompetensi Inti dan Kompetensi Dasar Pelajaran Pada Kurikulum 2013 pada Pendidikan Dasar dan Pendidikan Menengah

Prastyo, H., \& Salman, A. N. M. (2020). Pengembangan Soal Matematika Model Pisa Menggunakan Konteks Kalimantan Timur. Jurnal Pedagogik, 3(1), $1-44$. https://doi.org/https://doi.org/10.35974/jpd.v3i1.2230 Pengembangan

Ramlah, R., Bennu, S., \& Paloloang, B. (2017). Analisis Kesalahan Siswa dalam Menyelesaikan Soal Penjumlahan dan Pengurangan 
Pecahan di Kelas VII SMPN Model Terpadu Madani. Jurnal Ilmiah Pendidikan Matematika, 1(2), 182-194. https://doi.org/10.26877/jipmat.v1i2.1245

Rohmah, S. . (2019). Analisis Learning Obstacles Siswa pada Materi Pecahan Kelas IV Sekolah Dasar. Al-Aulad: Journal of Islamic Primary Education, 2(1), 13-24.

Sappaile, B. I. (2007). Hubungan Kemampuan Penalaran dalam Matematika dan Motivasi Berprestasi terhadap Prestasi Belajar Matematika. Jurnal Pendidikan Dan Kebudayaan, 69, 985-1003.

Siap, İ., \& Duru, A. (2004). The Ability to Use Geometrical Models in Fractions. Kastamonu Education Journal, 12(1), 89-96.

Siegler, R. S., Duncan, G. J., Davis-Kean, P. E., Duckworth, K., Claessens, A., Engel, M., Susperreguy, M. I., \& Chen, M. (2012). Early Predictors of High School Mathematics Achievement. Psychological Science, 23(7), 691-697. https://doi.org/10.1177/0956797612440101.

Suarjana, I. ., Parmiti, D. ., \& Safitri, P. E. A. (2018). Analisis Kesulitan Siswa dalam Menyelesaikan Operasi Hitung Pecahan Siswa Sekolah Dasar. International Journal of Elementary Education, 2(2), $144-155$.

https://doi.org/http://dx.doi.org/10.23887/ijee.v2i2.14417.

Suciati, I., \& Wahyuni, D. . (2018). Analisis Kesalahan Siswa dalam Menyelesaikan Soal Matematika pada Operasi Hitung Pecahan pada Siswa Kelas V SDN Pengawu. JPPM: Jurnal Penelitian Dan Pembelajaran Matematika, 11(2), 129-143.

Surya, E., Putri, F. A., \& Mukhtar. (2017). Improving mathematical problem-solving ability and self-confidence of high school students through the contextual learning model. Journal on Mathematics Education, 8(1), 85-94. https://doi.org/10.22342/jme.8.1.3324.8594.

Suryadi, D. (2010). Didactical Design Research (DDR) dalam Pengembangan Pembelajaran Matematika. Prosiding Seminar Nasional MIPA. Universitas Negeri Malang.

Suryadi, D. (2018). Ontologi dan Epistemologi dalam Penelitian Desain Didaktis (DDR). Bandung: Departemen Pendidikan Matematika 
UPI.

Susana, A. (2017). Penggunaan Metode Inkuiri untuk Meningkatkan Pemahaman Siswa Tentang Keliling dan Luas Lingkaran di SDN Gardusayang I Kecamatan Cisalak Kabupaten Subang. Jurnal Ilmiah Edukasi, 5, 43- 48.

Turmudi. (2008). Landasan Filsafat dan Teori Pembelajaran Matematika (Berparadigma Eksploratif dan Investigatif). Jakarta: Leuseur Cipta Pustaka.

Widodo, S., \& Kartikasari, K. (2017). Pembelajaran Pemecahan Masalah Matematis Siswa Sekolah Dasar Dengan Model Creative Problem Solving (Cps). Prisma, 6(1). https://doi.org/10.35194/jp.v6i1.28.

Wijaya, A. (2017). The Relationships between Indonesian Fourth Graders' Difficulties in Fractions and the Opportunity to Learn Fractions: A Snapshot of TIMSS Results. International Journal of Instruction, 10(4), $221-236$.

https://doi.org/https://doi.org/10.12973/iji.2017.10413a.

Zengin, Y. (2017). International Forum of Educational Technology \& Society Investigating the Use of the Khan Academy and Mathematics Software with a Flipped Classroom Approach in Mathematics Teaching. Journal of Educational Technology E Society, 20(2), 89-100. 